\title{
JPEB
}

Jurnal Penelitian Ekonomi dan Bisnis, 2 (1), 2017, Hal : 22 - 31

http://www.jpeb.dinus.ac.id

\section{STRUKTUR, KINERJA KEUANGAN DAN NILAI PERUSAHAAN (STUDI EMPIRIS INDUSTRI PERBANGKAN TAHUN 2007-2014 DI BURSA EFEK INDONESIA)}

\author{
Yulita Setiawanta ${ }^{*}$ dan Wuri Septiani ${ }^{2}$ \\ ${ }^{12}$ Program Studi Akuntansi, Fakultas Ekonomi dan Bisnis, Universitas Dian Nuswantoro \\ Jalan Nakula I No. 5-11, Semarang 50131, Indonesia \\ ${ }^{*}$ Corresponding Author: youseewhy70@dsn.dinus.ac.id
}

Diterima : November 2016; Direvisi : Januari 2016; Dipublikasikan : Maret 2017

\begin{abstract}
This study aims to confirm the signal theory through the relationship between the Company's Financial Structure that is proxied by the DER and the Company's Financial Performance which is proxied by ROE to increase the firm value proxied by $P B V$. The population in this study are the banking industries which listing at PT. IDX from 2007 to 2014. Using purposive sampling in searching for samples and found 140 sample data that are feasible to be processed by statistical tools, SPSS version 21 to confirmed the relationship between independent and dependent variables in this study. The results showed that signal theory was still very well confirmed in this study with evidence that all of the hypotheses proposed in this study proved to have a significant effect.
\end{abstract}

Keyword : DER; ROE; PBV; Firm Value

\begin{abstract}
ABSTRAK
Penelitian ini bertujuan untuk mengkonfirmasi teori sinyal melalui hubungan antara Struktur Keuangan Perusahaan yang diproksikan dengan DER dan Kinerja Keuangan Perusahaan yang diproksikan dengan ROE terhadap peningkatan nilai perusahaan yang diproksikan dengan PBV. Populasi dalam penelitian adalah industri perbankan yang listing di PT. BEI periode 2007 sampai 2014. Menggunakan purposive sampling dalam mencari sampel dan diperoeh sebanyak 140 data sampel yang layak untuk diolah oleh alat statistika SPSS versi 21 dalam mengkonfirmasi hubungan antar variabel independen dan dependen dalam penelitian ini. Hasil penelitian menunjukan bahwa teori sinyal masih terkonfirmasi dengan sangat baik dalam penelitian ini dengan bukti semua hipotesis yang diajukan dalam penelitian ini terbukti berpengaruh signifikan.
\end{abstract}

Kata kunci : DER; ROE; PBV; Nilai Perusahaan 


\section{PENDAHULUAN}

Setiap perusahan yang telah didirikan tentu secara kontinyu akan menjalankan kegiatan operasionalnya untuk mendapatkan keuntungan yang akan berdampak kepada meningkatnya nilai perusahaan (Apsari, Dwiatmanto, \& Azizah, 2015). Ketika perusahaan telah menjadi perusahaan public, hal tersebut dipandang sebagai upaya untuk meningkatkan nilai perusahaan. Dengan melakukan IPO maka perusahaan menjual sahamnya dipasar modal. Keberadaan pasar modal ini tentu saja guna mendukung perkembangan likuiditas perusahan. Disamping itu Pasar modal memiliki fugsi intermediasi transaksi dalam system perekonomian Negara (Meythi, 2012). Keberadaan pasar modal juga menambah alternatif sumber dana bagi setiap pelaku usaha yang pada akhirnya dapat memperbaiki struktur modal perusahaan.

Didalam pasar modal setiap transaksional yang terjadi sebagianya menggunakan dasar laporan keuangan yang diterbitkan oleh para emiten. Laporan keuangan tersebut diyakini memiliki kandungan informasi, Hal ini dapat dibuktikan pada saat publikasi dari laporan keuangan tersebut dapat menyebabkan timbulnya reaksi di pasar modal (Meythi, 2012). Jika perusahaan mampu meningkatkan profitabilitasnya, maka laba tersebut dapat dilihat pada rasiorasio laba yang dilaporkan dalam catatan laporan keuangan. Demikian juga dengan sumber pendanaan yang terdiri dari modal dan hutang sebagai bagian dari struktur modal, yang dapat dilihat pada nilai DER perusahaan (Apsari et al., 2015). Hal - hal tersebut tentunya di informasikan didalam setiap laporan keuangan peruahaan yang akan membawa manfaat bagi para pengambil keputusan (Nurhasanah, 2013).

Ketika perusahan dianggap oleh para Investor memiliki propek profitabilitas yang bagus dimasa yang akan datang, maka mereka mau membayar dengan harga tinggi untuk setiap lembar saham peruahaan. Untuk mengukur profitabilitas perusahaan dapat dilakukan dengan menggunakan rasio keuangan Return on Equity atau ROE sebagai pengembalian ekuitas pemegang saham (Ayu Sri Mahatma Dewi, 2013) atau Return on Equity (ROE) kemampuan modal sendiri dalam menghasilkan laba (Sartono, 2010).

Untuk mencapai tujuan perusahaan dukungan pendanaan yang tidak saja bersumber pada internal financing tetapi juga memiliki hubungan yang erat dengan eksternal financing seperti penguatan nilai hutang perusahaan, yang akhirnya menjadi komponen struktur modal perusahaan (Sartono, 2010). Ketika manajer keuangan perusahaan menjalankan pendanan bagi aktifitas operasional perusahaan maka komponen strultur modal menjadi perhatian yang serius bagi manajer tersebut (Dewa Ayu Prati Praidy Antari, 2014). Pengukuran struktur modal yang biasanya di proksikan dengan DER (Debt to Equity Ratio). DER sebagai cerminan kemampuan perusahaan dalam kepemilikan modal sendiri yang digunakan sebagai bagian dari pembayaran hutang. (Yuke Prabansari, 2005).

Penciptaan nilai perusahaan tentu juga menjadi bagian dari tujuan perusahaan yaitu pencapaian tingkat profitabilitas yang diinginkan di masa depan. Nilai perusahaan yang meningkat, tentu akan membawa pada peningkatan kesejahteraan para pemegang saham (Apsari et al., 2015). Price to book value (PBV).adalah rasio harga per nilai buku yang merupakan hubungan antara harga saham dengan nilai buku per lembar saham (Hidayati, 2010). Digunakan untuk mengukur nilai perusahaan, dengan konsep semakin besar rasio ini maka semakin tinggi nilai perusahaan. Nilai perusahaan dalam penelitian ini diproksikan dengan nilai PBV (Price Book Value) sebagai variabel dependen, dimana PBV merupakan jembatan persepsi calon investor dengan kondisi profitabilitas dan struktur modal peruahaan.

Penelitian ini mencoba melihat hubungan antara struktur modal perusahaan yang diprosikan dengan pendanaan perusahaan yang diukur melalui DER (debt to equity ratio) dengan nilai perusahaan yang diproksikan dengan PBV (price book value). Demikian juga untuk melihat hubungan antara Kinerja Keuangan yang diprosikan dengan profitabilitas yang diukur dengan ROE (return on equity). 
Yulita Setiawanta dan Wuri Septiani : Struktur, Kinerja Keuangan Dan Nilai Perusahaan (Studi Empiris Industri Perbangkan Tahun 2007-2014 Di Bursa Efek Indonesia)

\section{TINJAUAN PUSTAKA \\ Teori Sinyal}

Segala macam informasi bisa saja terjadi di pasar modal. Semua informasi tersebut akan ditangkap oleh para calon investor maupun investor yang telah berinvestasi sebelumnya. Kualitas informasi inilih yang menjadi bagian penting dalam teori signaling. Keputusan investasi yang dilakukan oleh pihak di luar perusahaan, sangat tergantung kepada pentingnya informasi yang diberikan oleh perusahaan terhadap mereka, disiniah peran utama dari teori sinyal (Spence, 1973) dan pihak lain, penerima, harus memilih cara menafsirkan sinyal tersebut (Connelly, Certo, Ireland, \& Reutzel, 2011). Pembayaran deviden akan meningkatkan keyakinan dihadapan para investor maupun calon investor akan keuntungan perusahaan yang dipergunakan untuk kesejahteraan mereka (Hidayati, 2010). Ketika perusahaan mampu meningkatkan rasio pembayaran deviden, para investor akan percaya bahwa manajemen mengumumkan perubahan positif kepada mereka. Misalkan juga pihak manajemen puncak melakukan langkah diversifikasi atas saham perusahaan (Maria Goranova, Todd M. Alessandri, 2007), maka mereka dengan segala sumberdaya akan mengkomunikasikan aktifitas manajemen tersebut, dengan harapan informasi atau sinyal yang di informasikan kepada publik itu dapat diangkat dan ditangkap dengan baik oleh para calon investor (Filatotchev \& Bishop, 2002).

\section{Teori Agensi}

Teori Keagenan (Agency Theory) merupakan peryataan miskomunikasi tujuan antara principal (pemilik suatu usaha) dengan agen (manajemen suatu usaha). (Jensen \& Meckling, 1976) menyatakan bahwa pusat pertemuan kontrak (nexus of contract) yang sistematis antara pemilik (principal) dan manajer (agent). Pada dasarnya agen bersifat oportunistik, atau mementingkan kepentingannya sendiri. Pemilik perusahaan memiliki cara tersendiri untuk mengatasi masalah keagenan dengan membuat employment contract yang mengatur tentang hak dan kewajiban bagi para pengelola, namun hak yang diberikan lebih menarik sehingga mampu mereduksi kepentingan opportunis dimasa yang akan datang (Gudono, 2009).

\section{Nilai Perusahaan}

Bukti kepemilikan investor dalam sebuah perusahaan yang berbadan hukum perseroan terbatas dinyatakan dalam bentuk saham. Nilai perusahaan dapat dimaknai jika semakin tinggi nilai perusahaan maka semakin tinggi pula minat calon investor untuk membeli saham perusahaan (Apsari et al., 2015). PBV merupakan rasio pasar yang digunakan untuk mengukur kinerja harga pasar saham terhadap nilai bukunya (Meythi, 2012). Semakin tinggi rasio PBV yang dilaporkan oleh perfusahaan mengandung makna bahwa perusahaan semakin berhasil dalam menciptakan nilai bagi shareholdernya (Hidayati, 2010). PBV dapat dipergunakan untuk mengukur nilai perusahaan, dirumuskan (Brigham, 2005) sebagai berikut :

$$
\begin{aligned}
& P B V=\frac{\text { Market price per Share }}{\text { Book Value per Share }} \\
& \text { Book Value per Share }=\frac{\text { Common Equality }}{\text { Share Outstanding }}
\end{aligned}
$$

\section{Return On Equity (ROE)}

Setiap kemampuan yang dimiliki oleh perusahaan dalam menghasilkan laba akan tercermin dalam setiap item ROE yang dilaporkan. Dimana ROE merupakan rasio kemampuan perusahaan dalam menghasilkan laba bersih yang akan dikembalikan kepada pemegang saham (Apsari et al., 2015). Pertumbuhan Return On Equity (ROE) yang di informasikan perusahaan 
kepada para calon investor dipersepsikan akan membawa semakin tinggi pula harga saham yang mungkin saja terbentuk pada setiap sesi penutupan transaksi dilantai bursa setiap harinya, ROE dapat dirumuskan (Brigham, 2005) sebagai berikut :

$$
\text { ROE }=\frac{\text { Net Profit After Tax }}{\text { Stockholders Equity }} \times 100 \%
$$

\section{Debt to Equity Ratio (DER)}

Struktur hutang perusahaan yang tentu saja mengandung biaya hutang tercermin dalam nilai Debt to Equity Ratio (DER) yang dilaporkan (Hidayati, 2010). Artinya seberapa besar kreditur bersedia menanggung pendanaan para debiturnya dan setiap debitur melaporkan posisi hutang tersebut secara jelas dan gambling. Pelaporan tersebut tercermin dalam rasio keuangan DER. Setiap rupiah yang dimiliki oleh perusahaan yang dijaminkan sebagai pembayaran hutang perusahan dimasa yang akan datang atau yang hendak jatuh tempo. DER menunjukkan semakin tinggi nilai DER, maka nilai hutang yang ditanggung perusahaan atas modal sendiri semakin tinggi (Apsari et al., 2015), ROE dapat dirumuskan (Brigham, 2005) sebagai berikut :

$$
\text { DER }=\frac{\text { Total Debt }}{\text { Total Equity }} \times 100 \%
$$

\section{Hipotesis}

Peryataan yang menunjukan hubungan dua variabel atau lebih yang memiliki keterikatan secara konsep atau teoritias yang harus dilakukan pengujian secara empiris disebut dengan hipotesis (Indriantoro, 2011).

Dalam hipotesis pertama ini dinyatakan bahwa tambahan hutang perusahaan masih diperkenankan sepanjang perusahaan masih memandang memiliki kemampuan untuk melakukan pembayaran hutang yang berasal dari modal sendiri. Apabila pengorbanan hutang sudah lebih besar, maka tambahan hutang sudah tidak diperlukan lagi (Hidayati, 2010). Berbagai penelitian menemukan hubungan antara struktur modal dengan PBV seperti (Mas'ud, 2008), (Doni Hendra, 2012), (Marlina, 2013), (Ayu Sri Mahatma Dewi, 2013), (Peatriex Pesiwarissa, 2014) dan (Ali, 2016) Berdasarkan uraian tersebut dalam penelitian ini hipotesis yang diajukan adalah sebagai berikut :

\section{$\mathrm{H}_{1}$ : Debt to Equity Ratio berpengaruh terhadap Nilai perusahaan}

Respon positif biasanya dilakukan oleh para investor pada saat mereka melihat perusahaan mampu menghasilkan keuntungan melalui modal sendiri, sehingga harga saham perusahaan mengalami kenaikan karena banyak dibeli oleh para investor dan pada akhirnya nilai PBV juga meningkat. Hasil penelitian (Wardjono, 2010), (Hidayati, 2010), (Doni Hendra, 2012), (Marlina, 2013), (Nurhasanah, 2013), (Khoiruddin \& Sudarsono, 2013), (Peatriex Pesiwarissa, 2014), (Apsari et al., 2015) dan (Ali, 2016) menunjukan hubungan diantara keduanya signifikan.

\section{$\mathrm{H}_{2}$ : Return On Equity berpengaruh terhadap Nilai perusahaan}

\section{METODE PENELITIAN}

Metode yang dipergunakan dalam penelitian ini adalah penelitian diskriptif kuantitatif. Jenis data yang dipergunakan adalah data sekunder yang diperoleh dari ICMD. Variabel penelitian ini adalah variabel independent (variabel bebas) yakni DER danROE sedangan kan variabel dependent nya adalah PBV (Nilai Perusahaan). Metode pengumpulan data melalui dokumentasi atas sumber-sumber data yang tersedia di ICMD pada periode pengamatan. 


\section{Populasi dan Sampel}

Populasi dalam penelitian ini adalah seluruh perusahaan yang bergerak dibidang perbankan yang listing di PT. BEI tahun 2007-2014. Sampel yang dipergunakan adalah dengan (judgement/purposive sampling), dengan kriteria yang ditentukan antara lain : seluruh perusahaan sampel melaporkan laporan keuangan berturut-turut selama periode pengamatan dan sampel tidak pernah membukukan kerugian operasional dalam laporan keuanganya selama masa periode pengamatan. Berdasarkan kriteria tersebut diperoleh jumlah sampel peruahaan yang memenuhi syarat dari 41 perusahaan perbankan yang tercatat adalah sebanyak 19 perusahaan. Masa observasi 8 tahun dengan demikian didapati data sampel sebanyak 152 data sampel (perusahaan) yang di obervasi untuk dilakukan pengambilan data yang diperlukan dalam setiap variabel penelitian yang digunakan.

\section{Teknik Analisis Data}

Pendekatan kuantitatif dilakukan didalam penelitian ini. Secara definisi pedekatan kuantitatif merupakan analisa data yang berwujud angka-angka dan mempergunakan perhitungan secara statistik untuk menjawab hipotesis yang diajukan. Penyajian dalam bentuk tabel, kurva atau grafik atas analisis ini menjadi hal yang utama dan dominan untuk menjelaskan hasil pengolahan data yang berhasil di identifikasi dengan baik dalam penelitian ini agar dapat ditarik suatu kesimpulan (Ghozali, 2013). Alat bantu yang digunakan adalah aplikasi SPSS (Statistical Package for Social Science). Versi 21. Dengan bantuan alat ini tahapan yang dilakukan adalah dengan melakukan pengolahan data yang berhasil di observasi untuk mencari statistik diskriftifnya kemudian melakukan pengujian kualitas data dengan asumsi klasik, melakukan pengujian model penelitian, menguji hipotesis dan terakhir menampilkan nilai koefisien deteminan atas data penelitian ini.

\section{HASIL DAN PEMBAHASAN Analisis Deskriptif}

Secara umum analisis deskriptif memberikan gambaran atau deskripsi suatu data yang dilihat dari jumlah sampel $(\mathrm{N})$, nilai maksimum, nilai minimum, nilai rata-rata (mean), dan standar deviasi. Sampel penelitian ini sebanyak 152 perusahaan perbankan dalam kurun waktu 8 tahun. Berikut ini adalah hasil analisis deskriptif dari DER, ROA dan PBV

Tabel 1. Statistik Diskriftif

\begin{tabular}{cccc}
\hline Variabel & Mean & Std Dev & N \\
\hline PBV & 1,8947 & 1,79390 & 152 \\
DER & 8,490964 & 2,7701123 & 152 \\
ROE &, 129655 &, 0631386 & 152 \\
\hline
\end{tabular}

Dari data tabel 1 dapat dinyatakan bahwa nilai standar deviasi semua variabel yang dipergunakan dalam penelitian ini berada pada posisi nilai yang lebih rendah dari nilai rata-rata setiap variabel dalam penelitin ini. Hal ini menunjukan bahwa data dalam penelitian ini tidak terdapat terdapat perbedaan yng tinggi antara data yang satu dengan data yang lain.

\section{Uji Kualitas Data (Asumsi Klasik)}

Uji kualitas data pada penelitian ini menggunakan uji asumsi klasik. Dari hasil uji asumsi klasik yang pertama yaitu, uji normalitas data dengan menggunakan tabel one-sampel kolmogorov smirnov pada pengujian pertama diperoleh nilai sebesar Asymp. Sig. (2-tailed) = 0,000. Dari nilai tersebut karena lebih kecil dari 0,005 maka dapat disimpulkan data penelitian 
yang diobservasi terdistribusi secara tidak normal. Langkah selanjutanya adalah melakukan identifikasi data eksterim untuk dilakukan proses outlier, dan diperoleh sebanyak 12 data ekstrim. Selanjutnya diproses normalitas data secara ulang dengan jumlag data 140 (dari 152 semula). Berdasarkan pengolahan data tersebut ditemukan nilai sebesar Asymp. Sig. (2-tailed) $=0,157$. Dari nilai tersebut karena lebih besar dari 0,005 maka dapat disimpulkan data penelitian yang diobservasi terdistribusi secara normal.

Tindakan selanjutnya adalah melihat nilai multikoliniearitasnya. Cara mendeteksi ada tidaknya multikoliniearitas dapat dilihat dalam model regresi dengan melihat tolerance dan lawannya yaitu VIF, yaitu Jika nilai tolerance $\geq 0,1$ atau jik VIF $\leq 10$, maka tidak terdapat multikoliniritas dalam model regresi. Jika Jika nilai tolerance $\leq 0,1$ atau jik VIF $\geq 10$, maka terdapat multikoliniritas dalam model regresi. Berikut tabel multikoliniearitas :

Tabel 2. Uji Multikoliniritas

\begin{tabular}{ccc}
\hline Model & Tolerance & VIF \\
\hline DER &, 987 & 1,013 \\
ROE &, 987 & 1,013 \\
\hline
\end{tabular}

Berdasarkan tabel 2 tersebut diatas maka semua posisi nilai tolerance $\geq 0,1$ atau jika $\mathrm{VIF} \leq 10$, maka tidak terdapat multikoliniritas dalam model regresi pada penelitian ini.

Uji autokorelasi Dengan menggunakan tabel model summary jika nilai durbin-watson berada pada nilai diantara $\mathrm{du}<\mathrm{DW}<4$-du, maka $1,760<1,800<4-1,760$ atau $1,760<1,800<2,240$ maka dapat dikatakan tidak terjadi autokolerasi dalam data penelitian ini. Berdasarkan hasil pengolahan data diketahui nilai Durbin_Watsonya adalah sebesar : 1,800 maka dapat dikatakan tidak terjadi autokorelasi. Berikut informasi dalam tabel 3.

Tabel 3. Uji Autokorelasi

\begin{tabular}{ccc}
\hline Model & R & $\begin{array}{c}\text { Durbin } \\
\text { Watson }\end{array}$ \\
\hline 1 & $\mathrm{a}$ & 1,800 \\
\hline
\end{tabular}

Uji Heterokedastisitas menguji apakah dalam model regresi terjadi ketidak bersamaan variance dari residual satu pengamatan ke pengamatan yang lain.

Tabel 4. Uji Heterokedastisitas

\begin{tabular}{cccc}
\hline Model & Beta & T & Sig \\
\hline DER &, 005 &, 388 &, 698 \\
ROE &, 883 & 1,627 &, 106
\end{tabular}

Berdasarkan tabel 4 diatas diperoleh hasil bahwa semua nilai signifikansi semua diatas 0,05 yang berarti bahwa tidak terdapat gangguan heteroskedastisitas pada setiap variabel independennya.

\section{Uji Model}

Dengan menggunakan asil uji F/ANOVA dalam penelitian ini, maka dapat dikatakan jika tingkat signifikan dibawah dari 0,05 maka model dalam penelitian dapat dikatakan FIT atau bagus, berikut tabel uji F/ANOVA dibawah ini :

Tabel 5. Uji F/ANOVA 


\begin{tabular}{cccc}
\hline Model & $\begin{array}{c}\text { Mean } \\
\text { Squrae }\end{array}$ & F & Sig \\
\hline Regression & 39,090 & 88,954 &, $000^{\mathrm{b}}$ \\
\hline
\end{tabular}

Berdasarkan tabel 5 ditas maka dapat dikatakan model regresi penelitian ini adalah FIT atau Bagus. Hal tersebut mengandung arti bahwa model penelitian yang menghubungkan variabel Independen terhadap variabel dependen dalam penelitian ini adalah layak uji.

\section{Uji Hipotesis}

Hipotesis yang kita ajukan diterima atau ditolak maka, disajikan dalam beberapa kolom,seperti pada tabel 6 dibawah ini :

Tabel 6. Coefficients ${ }^{a}$

\begin{tabular}{cccc}
\hline Model & Beta & T & Sig \\
\hline Constant &, 544 & 2,660 &, 009 \\
DER &,- 047 & $-2,336$ &, 021 \\
ROE & 11,999 & 13,313 &, 000 \\
\hline
\end{tabular}

Berdasarkan tabel 6. Daiatas maka didapatkan model persamaan regresi akhir sebagai berikut :

$$
\text { PBV = 0,544 - 0,047 DER + 11,999 ROE + e }
$$

Dengan demikian untuk peryataan jawaban hipotesis yang dibangun dapat dikatakan bahwa : Nilai signifikansi DER sebesar 0,021 < 0,05 dapat disimpulkan bahwa variabel DER berpengaruh terhadap Nilai Perusahaan. Dengan demikian hipotesis pertama terbukti (H1 diterima). Nilai signifikansi ROE sebesar $0,000<0,05$ dapat disimpulkan bahwa variabel ROE berpengaruh terhadap Nilai Perusahaan. Dengan demikian hipotesis kedua terbukti (H2 diterima)

\section{Koefisien Determinan}

Menurut (Ghozali, 2013) uji koefisiensi determinasi dilihat dari nilai nilai adjusted $R$ square dan didalam penelitian ini diperoleh nilai adjusted $R$ square sebesar 0,559, maka dapat diartikan bahwa variabel independen (DER dan $R O E)$ menjelaskan variabel dependen PBV (Nilai Perusahaan) sebesar 55,90\% sedangkan sisanya diterangkan oleh faktor lain yang tidak diamati dalam penenlitian ini

\section{HASIL DAN PEMBAHASAN}

\section{Struktur Keuangan Perusahaan : Debt to Equity (DER) Berpengaruh terhadap Nilai Perusahaan.}

Dengan terbuktinya pengaruh DER terhadap Nilai perusahaan dalam penelitian ini patut diduga terkontribusi dengan karakteristik data penelitian yang sesuai dengan konsep dasar yang dibangun oleh peneliti. Dimana peneliti menyatakan bahwa jika dalam kondisi nilai DER entitas sampel penelitian mengalami kenaikan maka akan membawa kecenderungan turunya nilai perusahaan pada entitas sampel tersebut. Hal ini terbukti dengan fakta data sampel yang dimiliki oleh PT. Bank Negara Indonesia pada tahun 2008, dengan nilai DER sebesar 12,076 atau lebih besar sebesar $42,22 \%$ dari nilai DER rata-rata sampel yang berada pada nilai sebesar 8,4909 dan memiliki nilai PBV sebesar 0,67 atau lebih kecil sebesar 64,63\% dari nilai rata-rata PBV sampel yang berada pada nilai sebesar 1,8947 . 
Berdasarkan data tersebut dapat dinyatakan bahwa karakteristik data penelitian dalam penelitian ini pada hubungan antara variabel DER terhadap PBV sesuai dengan konsep dasar yang dibangun oleh peneliti. Dimana semakin besar nilai DER perusahaan sampel maka akan semakin kecil nilai PBV perusahaan sampel dan hal tersebut terbukti. Dengan demikian karakteristik data lain yang sejenis dengan data ini patut diduga mengkontribuasi hasil signifikansi hubungan kedua variabel tersebut.

Demikian pulas secara teoritis dalam operasional perusahaan pada posisi Debt to Equity Ratio (DER) yang semakin meningkat, maka jumlah kewajiban perusahaan, seperti bunga pinjaman dan pembayaran pinjaman akan semakin menngkat. Hal ini akan direspon negatif oleh investor sebagai implementasi teori sinyal (bad news) yang di informasikan perusahaan. Hal ini mendorong nilai Price Book Value semakin menurun, sebab kemampuan perusahaan untuk menghasilkan laba akan semakin berkurang sebagai akibat dari pembayaran bunga dan pinjaman yang tinggi..

Hasil penelitian ini mendukung hasil penelitian sebelumnya yang dilakukan oleh (Mas'ud, 2008), (Doni Hendra, 2012), (Marlina, 2013), (Ayu Sri Mahatma Dewi, 2013), (Peatriex Pesiwarissa, 2014) dan (Ali, 2016). Meskipun demikian hasil penelitian yang berbeda juga ditemukan oleh (Hidayati, 2010), (Khoiruddin \& Sudarsono, 2013), (Dewa Ayu Prati Praidy Antari, 2014) dan (Apsari et al., 2015).

\section{Kinerja Keuangan Perusahaan : Return on Equity (ROE) Berpengaruh terhadap Nilai Perusahaan.}

Demikian pula Dengan terbuktinya pengaruh ROE terhadap Nilai perusahaan dalam penelitian ini patut diduga terkontribusi dengan karakteristik data penelitian yang sesuai dengan konsep dasar yang dibangun oleh peneliti. Dimana peneliti menyatakan bahwa jika dalam kondisi nilai ROE entitas sampel penelitian mengalami kenaikan maka akan membawa kecenderungan naiknya nilai perusahaan pada entitas sampel tersebut. Hal ini terbukti dengan fakta data sampel yang dimiliki oleh PT. Bank Central Asia pada tahun 2008, dengan nilai ROE sebesar 9,5488 atau lebih besar sebesar $7268 \%$ dari nilai ROE rata-rata sampel yang berada pada nilai sebesar 0,1296 dan memiliki nilai PBV sebesar 2,4810 atau lebih besar sebesar 30,78\% dari nilai rata-rata PBV sampel yang berada pada nilai sebesar 1,8947.

Berdasarkan data tersebut dapat dinyatakan bahwa karakteristik data penelitian dalam penelitian ini pada hubungan antara variabel ROE terhadap PBV sesuai dengan konsep dasar yang dibangun oleh peneliti. Dimana semakin besar nilai ROE perusahaan sampel maka akan semakin besar nilai PBV perusahaan sampel dan hal tersebut terbukti. Dengan demikian karakteristik data lain yang sejenis dengan data ini patut diduga mengkontribuasi hasil signifikansi hubungan kedua variabel tersebut.

Demikian pula secara teoritis dalam operasional perusahaan digambarkan posisi Return on Equity (ROE) merupaka informasi yang diangap sebagai informasi yang positip atau sinyal yang baik yang di informasikan oleh perusahaan kepada para calon investor atau investornya. Dalam hal ini teori sinyal dapat terkonfirmasi dengan sangat baik dalam hubungan diantara variabel yang diteliti.

Hasil penelitian ini mendukung hasil penelitian sebelumnya yang dilakukan oleh (Wardjono, 2010), (Hidayati, 2010), (Doni Hendra, 2012), (Marlina, 2013), (Nurhasanah, 2013), (Khoiruddin \& Sudarsono, 2013), (Peatriex Pesiwarissa, 2014), (Apsari et al., 2015) dan (Ali, 2016). Meskipun demikian hasil penelitian yang berbeda juga ditemukan oleh (Istikhanah, 2015) dan (Wicaksono, 2015).

\section{SIMPULAN}

Kesimpulan yang bisa diambil dalam penelitian ini adalah bahwa variabel DER sebagai pengukuran struktur keuangan perusahaan dan ROE sebagai pengukuran kinerja keuangan 
perusahaan memiliki pengaruh signifikan terhadap nilai perusahaan (PBV). Hal ini yang mendorong saran kepada calon investor dimasa yang akan datang jika ingin berinvestasi pada perusahaan sampel dalam penelitian ini sebaiknya calon investor mempergunakan informasi fundamental yang ada dalam laporan keuangan yang dipublikasikan.Calon investor diharapkan dapat melihat nilai atau tren dari DER dan ROE nya jika tren nya mengalami peningkatan maka patut diduga bahwa nilai perusahaannya (PBV) juga akan mengalami pertumbuhan yang baik saran yang lain adalah hendaknya peneliti yang akan datang mencari variebel pemoderasi hubungan antara DER,dan ROE terhadap Nilai Perusahaan.

\section{DAFTAR PUSTAKA}

Ali, M. 2016. Pengaruh return on equity, debt to equity ratio (DER) dan Growth terhadap price to book value (PBV). Conference on Management and Behavioral Studies2, 829-840.

Apsari, I. A., Dwiatmanto, \& Azizah, D. F. 2015. Pengaruh Return on Equity, Net Profit Margin, Debt to Equity Ratio, dan Longterm Debt to Equity Ratio Terhadap Price Book Value (Studi Pada Perusahaan Sub Sektor Makanan dan Minuman yang Terdaftar di Bursa Efek Indonesia Periode Tahun 2010-2013). Jurnal Administrasi Bisnis (JAB). 27(2), 1-8.

Sri Mahatma Dewi, A. W. (2013). Pengaruh struktur modal, profitabilitasdanukuran perusahaan terhadap nilai perusahaan. E-Jurnal Akuntansi Universitas Udayana2. 4(2): 358-372.

Brigham, E. F. dan M. C. E. 2005. Financial Management: Theory and Practice. SouthWestern : Cengange Learning.

Connelly, B. L., Certo, S. T., Ireland, R. D., \& Reutzel, C. R. 2011. Signaling theory: A review and assessment. Journal of Management. 37(1): 39-67.

Dewa Ayu Prati Praidy Antari, I. M. D. 2014. Pengaruh Struktur Modal, Kepemilikan Manajerial, Dan Kinerja Keuangan Terhadap Nilai Perusahaan. Fakultas Ekonomi Universitas Udayana, 274-288.

Doni Hendra. 2012. Analisis faktor-faktor yang mempengaruhi price book value (PBV) : studi empiris emiten industri barang komsumsi periode 2007-2010. Jurnal MIX. 2(3): 280-291.

Filatotchev, I., \& Bishop, K. 2002. Board composition, share ownership, and underpricing' of U.K. IPO firms. Strategic Management Journal. 23(10): 941-955.

Ghozali, I. 2013. Aplikasi Analisis Multivariate Dengan Program IBM SPSS 21. Semarang: BP Universitas Diponegoro .

Gudono. 2009. Teori Organisasi (2nd ed.). Yogyakarta: BPFE Yogyakarta.

Hidayati, E. E. 2010. Analisis Pengaruh DER, DPR, ROE dan Size terhadap PBV Perusahaan Manufaktur yang Listing di BEI Periode 2005-2007. Jurnal Bisnis. 19(2):166-174.

Indriantoro, N. dan B. S. 2011. Metodologi Penelitian Bisnis Untuk A kuntansi Dan Manajemen. Yogyakarta: BPFE.

Istikhanah. 2015. Pengaruh Return on Asset (ROA) dan retirn on Equity (ROE) terhadap nilai perusahaan.

Jensen, M. C., \& Meckling, W. H. 1976. Theory of the Firm: Managerial Behavior, Agency Costs and Ownership Structure. Journal of Financial Economics. 3(4): 305-360.

Khoiruddin, M., \& Sudarsono, M. A. 2013. Penentu Nilai Perusahaan Penerbit Efek Syariah. Seminar and Call for Paper 2015 : Srategic Agility: Thrive in Turbulent Environment, 117.

Maria Goranova, Todd M. Alessandri, P. B. and R. D. 2007. Managerial Ownership and Corporate Diversification: A Longitudinal Vuew. Strategic Management Journal. 28(1): 211-225.

Marlina, T. 2013. Pengaruh Earning Per Share, Return On Equity, Debt To Equity Ratio dan Size Terhadap Price To Book Value. Jurnal Ilmiah Akuntansi Kesatuan. 1(1): 59-72.

Mas'ud, M. 2008. Analisis Faktor-Faktor Yang mempengaruhi struktur modal dan hubunganya dengan nilai perusahaan. Manajemen Dan Bisnis, 7(1). 
Meythi. 2012. Pengaruh Price Earning Ratio dan Price Book Value terhadap Harga Saham Indeks LQ 45 (Periode 2007-2009). Jurnal Akuntansi, 4(1), 1-21.

Nurhasanah, R. 2013. Pengaruh return on assets (ROA), Return on equity (ROE), dan Earning per share (EPS) terhadap harga saham (Survey Pada Perusahaan LQ 45 yang Terdaftar di Bursa Efek Indonesia Periode 2007-2011. Jurnal Akuntansi, Fakultas Ekonomi, Universitas Widyatama. 34(2).

Peatriex Pesiwarissa, N. S. 2014. Analisis pengaruh debt to equity ratio (DER), return on equity (ROE) dan earning per share (EPS) terhadap nilai perusahaan. Jurnal Manajemen, Akuntansi Dan Studi Pembangunan. 13(2): 48-59.

Sartono, A. 2010. Manajemen Keuangan Teori dan Aplikasi. (4th ed.). Yogyakarta: BPFE.

Spence, M. 1973. Job Market Signaling. The Quarterly Journal of Economics. 87(3).

Wardjono, W. 2010. Analisis faktor-faktror yang mempengaruhi price to book value dan implikasinya pada return saham (Studi Kasus pada Perusahaan Manufaktur yang Terdaftar di BEI). Dinamika Keuangan Dan Perbankan. 2(1).

Wicaksono, R. B. 2015. Pengaruh EPS, PER, DER, ROE dan MVA terhadap harga saham Semarang: Universitas Dian Nuswantoro.

Yuke Prabansari, H. K. 2005. Faktor-faktor yang mempengaruhi struktur modal perusahaan manufaktur go publik di bursa efek Indonesia. Sinergi. Edisi khusus(1), 1-15. 